\title{
Exiguobacterium profundum sp. nov., a moderately thermophilic, lactic acid-producing bacterium isolated from a deep-sea hydrothermal vent
}

Correspondence Yannick Combet-Blanc yannick.combet-blanc@ univmed.fr

\section{Sylvaine Crapart, Marie-Laure Fardeau, Jean-Luc Cayol, Pierre Thomas, Christian Sery, Bernard Ollivier and Yannick Combet-Blanc}

IRD, UMR180, IFR-BAIM, Universités de Provence et de la Méditerranée, ESIL case 925, 163 Avenue de Luminy, 13288 Marseille Cedex 9, France

\begin{abstract}
A facultatively anaerobic, halotolerant, moderately thermophilic and non-sporulating bacterium, designated strain $10 \mathrm{C}^{\top}$, was isolated from deep-sea hydrothermal vent samples collected on the $13^{\circ} \mathrm{N}$ East Pacific Rise at a depth of approximately $2600 \mathrm{~m}$. Cells of strain $10 \mathrm{C}^{\top}$ were Grampositive, motile rods, and grew optimally at $45^{\circ} \mathrm{C}$ (range $12-49^{\circ} \mathrm{C}$ ), $\mathrm{pH} 7.0$ (range $\mathrm{pH} 5.5-9.5$ ) and $0-2 \% \mathrm{NaCl}$ (range $0-11 \%)$. (+)-L-Lactate was the main organic acid detected from carbohydrate fermentation with traces of formate, acetate and ethanol. Strain $10 \mathrm{C}^{\top}$ was catalasepositive, oxidase-negative and reduced nitrate to nitrite under anaerobic conditions. The DNA $\mathrm{G}+\mathrm{C}$ content was $50.4 \mathrm{~mol} \%$. Its closest phylogenetic relatives were Exiguobacterium aestuarii $\mathrm{TF}-16^{\top}$ and Exiguobacterium marinum TF-80 ${ }^{\top}$ (16S rRNA gene sequence similarity >99\%). However, strain $10 C^{\top}$ differed genotypically from these two Exiguobacterium species as indicated by DNA-DNA relatedness data. Therefore, on the basis of phenotypic, genotypic and phylogenetic characteristics, strain $10 \mathrm{C}^{\top}$ is considered to represent a novel species of the genus Exiguobacterium, for which the name Exiguobacterium profundum sp. nov. is proposed. The type strain is $10 C^{\top}\left(=\right.$ CCUG $50949^{\top}=$ DSM $\left.17289^{\top}\right)$.
\end{abstract}

Deep-sea hydrothermal vents are characterized by sharp physical and chemical gradients that support the growth of a wide range of hyperthermophilic, psychrophilic and mesophilic micro-organisms, including anaerobes, aerobes and microaerophiles (Jeanthon, 2000; Karl, 1995). In these dark ecosystems, the primary energy source for life is supplied by various reduced sulfur compounds originating from the hydrothermal fluid. Besides these compounds, the presence of toxic heavy metals (Edmond \& Von Damm, 1985; Juniper \& Sarrizan, 1995; Luther et al., 2001a, b; Rozan et al., 2000) also constitutes an important selective pressure on the micro-organisms that inhabit deep-sea hydrothermal vents (Michard et al., 1984; Von Damm et al., 1985a, b; Bowers et al., 1988).

Relatively few studies have investigated mesophiles and moderate thermophiles among the heterotrophic anaerobic microbial groups thriving in deep-sea environments (Campbell et al., 2001; Brisbarre et al., 2003) compared with thermophiles and hyperthermophiles belonging to the Bacteria and Archaea (Baross \& Deming, 1995; Jeanthon et al., 1998; L'Haridon et al., 1998; Reysenbach et al., 2000a, b; Wery et al., 2001; Alain et al., 2002a, b; Götz et al., 2002). Here we report on the isolation from a deep-sea

The GenBank/EMBL/DDBJ accession number for the 16S rRNA gene sequence of strain $10 C^{\top}$ is $A Y 818050$. hydrothermal vent on the $13^{\circ} \mathrm{N}$ East Pacific Rise of a novel, moderately thermophilic, anaerobic, homolactic fermentative bacterium (strain $10 \mathrm{C}^{\mathrm{T}}$ ) belonging to the genus Exiguobacterium, order Bacillales, family Bacillaceae. The genus Exiguobacterium was first described by Collins et al. (1983) on the basis of chemotaxonomic studies (cell-wall peptidoglycan composition, DNA G $+\mathrm{C}$ content and cell membrane lipid composition) and phenotypic features as all members of the genus are alkaliphiles. Further studies based on 16S rRNA gene sequence analysis (Farrow et al., 1994) supported the validity of the genus Exiguobacterium as a distinct clade at the boundary of the bacilli group 2 cluster (Ash et al., 1991). At the time of writing, the genus Exiguobacterium comprised ten recognized species: Exiguobacterium aurantiacum (Collins et al., 1983) (the type species), E. acetylicum (Jones \& Keddie, 1986), E. undae, E. antarcticum (Frühling et al., 2002), E. oxidotolerans (Yumoto et al., 2004), E. aestuarii, E. marinum (Kim et al., 2005), E. mexicanum, E. artemiae (Lopez-Cortes et al., 2006) and E. sibiricum (Rodrigues et al., 2006), isolated from various industrial wastes, freshwater and marine environments.

Strain $10 \mathrm{C}^{\mathrm{T}}$ was isolated from a deep-sea hydrothermal chimney sample collected from the Grandbonum vent site $\left(13^{\circ} \mathrm{N} 103^{\circ} 56^{\prime} \mathrm{W}\right.$ along the East Pacific Rise at a depth of $2600 \mathrm{~m}$ ) in June 1999 during the Amistad cruise using the deep-sea submarine Nautile. Samples were stored in 
seawater at $4{ }^{\circ} \mathrm{C}$ until processing. Hungate technique (Hungate, 1969) was used throughout this study. The basal medium (BM) contained (per litre distilled water): $1 \mathrm{~g}$ $\mathrm{NH}_{4} \mathrm{Cl}, 0.3 \mathrm{~g} \mathrm{~K}_{2} \mathrm{HPO}_{4}, 0.3 \mathrm{~g} \mathrm{KH}_{2} \mathrm{PO}_{4}, 25 \mathrm{~g} \mathrm{NaCl}, 0.2 \mathrm{~g}$ $\mathrm{CaCl}_{2}, 0.1 \mathrm{~g} \mathrm{KCl}, 3.0 \mathrm{~g} \mathrm{MgCl}_{2} \cdot 6 \mathrm{H}_{2} \mathrm{O}, 0.5 \mathrm{~g}$ sodium acetate, $0.5 \mathrm{~g}$ cysteine hydrochloride, $0.1 \mathrm{~g}$ yeast extract (Difco laboratories), $10 \mathrm{ml}$ of the trace mineral element solution of Balch et al. (1979) and $1 \mathrm{mg}$ resazurin (Sigma). The $\mathrm{pH}$ was adjusted to 7.3 with $10 \mathrm{M} \mathrm{KOH}$. The medium was boiled under a stream of $\mathrm{O}_{2}$-free $\mathrm{N}_{2}$ gas and cooled to room temperature. Five-millilitre aliquots were dispensed into Hungate tubes and $20-\mathrm{ml}$ aliquots were dispensed into serum bottles under a stream of $\mathrm{N}_{2} / \mathrm{CO}_{2}(80: 20, \mathrm{v} / \mathrm{v})$, and the sealed vessels were then autoclaved for $45 \mathrm{~min}$ at $110{ }^{\circ} \mathrm{C}$. Prior to inoculation, $\mathrm{Na}_{2} \mathrm{~S} .9 \mathrm{H}_{2} \mathrm{O}, \mathrm{NaHCO}_{3}$ and D-glucose were injected from sterile stock solutions to final concentrations of $0.04 \%(\mathrm{w} / \mathrm{v}), 0.2 \%(\mathrm{w} / \mathrm{v})$ and $20 \mathrm{mM}$, respectively. The serum bottles containing $\mathrm{BM}$ were inoculated with $2 \mathrm{ml}$ sample and incubated at $45^{\circ} \mathrm{C}$ to initiate an enrichment culture. The culture was purified by using a repeated Hungate roll-tube method with BM solidified with 15 g agar $\mathrm{l}^{-1}$.

$\mathrm{pH}$, temperature and $\mathrm{NaCl}$ growth experiments were performed in duplicate, by using Hungate tubes containing $\mathrm{BM}$ and D-glucose $(20 \mathrm{mM})$ as energy source. Prior to inoculation, strain $10 \mathrm{C}^{\mathrm{T}}$ was subcultured at least once under the same experimental conditions. For all experiments, bacterial growth was monitored by measuring the increase in turbidity at $580 \mathrm{~nm}$ in anaerobic tubes inserted directly into a model UV-160A spectrophotometer (Shimadzu). The presence of spores was sought by microscopic examination of the culture at different phases of growth. In addition, the heat resistance of cells was tested in duplicate by using BM supplemented with D-glucose $(20 \mathrm{mM})$. After 1,2 and 8 days incubation, the cultures were heated at $80{ }^{\circ} \mathrm{C}$ for 5 and $10 \mathrm{~min}$, transferred into fresh medium $(20 \%, \mathrm{v} / \mathrm{v})$ and incubated at $45^{\circ} \mathrm{C}$. Under anaerobic conditions, substrates to be tested were injected, from sterile stock solutions, to a final concentration of $20 \mathrm{mM}$ into Hungate tubes containing BM, and growth was followed by measuring turbidity at $580 \mathrm{~nm}$. For substrates to be tested under aerobic conditions, culturing was carried out in Erlenmeyer flasks containing BM supplemented with yeast extract $\left(0.2 \mathrm{~g} \mathrm{l}^{-1}\right.$ final concentration). The use of elemental sulfur $(2 \%, \mathrm{w} / \mathrm{v})$, thiosulfate $(20 \mathrm{mM})$, sulfate $(20 \mathrm{mM})$, sulfite $(2 \mathrm{mM})$, nitrate $(10 \mathrm{mM})$, nitrite $(10 \mathrm{mM})$ and fumarate $(20 \mathrm{mM})$ as terminal electron acceptors was tested using BM supplemented with D-glucose (20 mM) as energy source. Light and electron microscopy were performed as described by Cayol et al. (1994). Analytical techniques were used as described by Fardeau et al. (1993). (+)-L-Lactate dehydrogenase and ( - )-D-lactate dehydrogenase (Boehringer Mannheim) were used to assess the stereoisomeric state of the lactic acid produced by fermentation of glucose. Nitrate and nitrite utilization were tested by using the kit Quantofix (Macherey-Nagel). Oxidase activity was tested by using Bio-Rad oxidase disks. Polar lipid, quinone and fatty acid analysis, determination of the $\mathrm{G}+\mathrm{C}$ content of the DNA and DNA-DNA hybridization experiments were carried out by the Identification Service of the Deutsche Sammlung von Mikroorganismen und Zellkulturen $\mathrm{GmbH}$ (Braunschweig, Germany). For fatty acid analysis of strain $10 \mathrm{C}^{\mathrm{T}}$, cellular biomass was produced on solid agar medium as described by Kim et al. (2005). The peptidoglycan was isolated and its structure determined by using the methods described by Schleifer \& Kandler (1972), Schleifer (1985), Groth et al. (1996) and MacKenzie (1987). Methods for the purification and extraction of DNA and the amplification and sequencing of the $16 \mathrm{~S}$ rRNA gene were as described by Ben DhiaThabet et al. (2004), except for the use of primer Rd1 (5'-AAGGAGGTGATCCAGCC-3') instead of R6. Samples were loaded onto an Applied Biosystems 373XL sequencer and run for $12 \mathrm{~h}$ on a $4.5 \%$ denaturing acrylamide gel by Genome Express Co. Sequence data were imported into the sequence editor BIOEDIT version 5.0.9 (Hall, 1999), the basecalling was examined and a contiguous consensus sequence was obtained for each isolate. The full sequence was aligned using the Ribosomal Database Project's (RDP) Sequence Aligner program (Maidak et al., 2001). The consensus sequence was then manually adjusted to conform to the $16 \mathrm{~S}$ rRNA gene secondary structure model (Winker \& Woese, 1991). A non-redundant BLASTN search (Altschul et al., 1997) of the full sequence through GenBank (Benson et al., 1999) identified its closest relative. Sequences used in the phylogenetic analysis were obtained from the RDP (Maidak et al., 2001) and GenBank (Benson et al., 1999). Positions of sequence and alignment ambiguity were omitted, and pairwise evolutionary distances based on 1342 unambiguous nucleotides were calculated using the method of Jukes \& Cantor (1969). Dendrograms were constructed using the neighbour-joining method (Saitou \& Nei, 1987). Confidence in tree topology was determined by using 100 bootstrapped trees (Felsenstein, 1985).

Enrichment of cultures and purification were conducted at $45^{\circ} \mathrm{C}$ under anaerobic conditions. Creamy, circular colonies ( $2 \mathrm{~mm}$ in diameter) appeared after 3 days incubation in roll tubes. Several strains showing similar cell morphology and displaying homolactic metabolism were isolated, but only strain $10 \mathrm{C}^{\mathrm{T}}$ was characterized further. Microscopic examination revealed the presence of nonspore-forming, rod-shaped cells $(0.5-1.0 \times 2-10 \mu \mathrm{m})$ occurring singly or in pairs, and motile by means of peritrichous flagella. Electron microscopy of cellular sections revealed a thick, stratified Gram-positive-type cell wall, composed of three layers, an internal thick layer and a thinner external layer separated by a light space. Cell-wall analysis revealed that the peptidoglycan type of strain $10 \mathrm{C}^{\mathrm{T}}$ was A $3 \alpha$ L-Lys-Gly.

Analysis of the most recent 16S rRNA gene sequences available from the RDP and GenBank revealed that strain $10 \mathrm{C}^{\mathrm{T}}$ belonged to the genus Exiguobacterium, order Bacillales, family Bacillaceae, with E. aestuarii $\mathrm{TF}-16^{\mathrm{T}}$ and E. marinum $\mathrm{TF}-80^{\mathrm{T}}$ (Kim et al., 2005) being its closest 


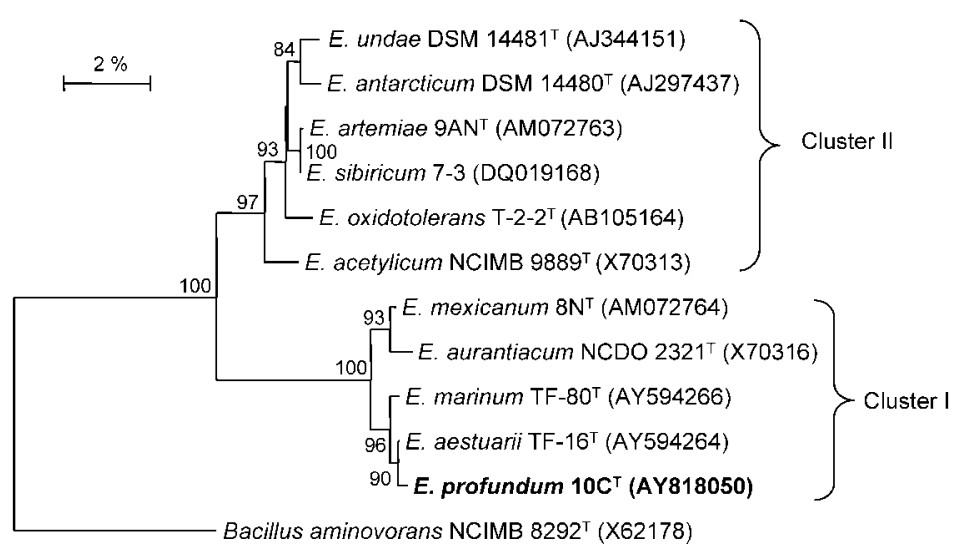

Fig. 1. Neighbour-joining phylogenetic dendrogram based on 16S rRNA gene sequence data indicating the position of strain $10 C^{\top}$ among members of the genus Exiguobacterium. Accession numbers of $16 \mathrm{~S}$ rRNA gene sequences of reference organisms are indicated. Bootstrap values from 100 replications are shown at branching points; only values above 80 are shown. Bar, 2 substitutions per 100 nt. phylogenetic relatives (99.78 and $99.48 \%$ sequence similarity, respectively) (Fig. 1).

As with other members of the genus Exiguobacterium, strain $10 \mathrm{C}^{\mathrm{T}}$ exhibited growth under alkaline conditions (up to $\mathrm{pH}$ 9.5) and was halotolerant, growing in the presence of $\mathrm{NaCl}$ concentrations ranging from 0 to $110 \mathrm{~g} \mathrm{l}^{-1}$, with optimum growth at $0-20 \mathrm{~g} \mathrm{l}^{-1}$. However, strain $10 \mathrm{C}^{\mathrm{T}}$ differed markedly from recognized mesophilic Exiguobacterium species as it exhibited the highest optimum temperature $\left(45^{\circ} \mathrm{C}\right)$ for growth, which may reflect its origin within a deep-sea hydrothermal vent. It must therefore be considered as a moderate thermophile, as it grew optimally at temperatures above $40-42{ }^{\circ} \mathrm{C}$ (the defined limit for growth of mesophilic micro-organisms) and at up to $49^{\circ} \mathrm{C}$ (Table 1). Under anaerobic conditions, strain $10 C^{\mathrm{T}}$ fermented glucose mainly into (+)-L-lactic acid with traces of formate, acetate and ethanol. The molar ratio of 2 moles lactate produced per mole glucose fermented corresponded to a homolactic fermentative pattern for strain $10 \mathrm{C}^{\mathrm{T}}$. Although some Exiguobacterium species have been described as heterolactic fermentative bacteria (lactate, acetate, ethanol and formate being the main end products of metabolism), it is well known that the fermentative pattern depends to a large degree on the culture conditions. Strain $10 \mathrm{C}^{\mathrm{T}}$ grew aerobically in BM medium only in the presence of yeast extract $\left(0.2 \mathrm{~g} \mathrm{l}^{-1}\right)$ and must be considered as a facultative anaerobe. In the presence of oxygen, glucose was first oxidized to $\mathrm{CO}_{2}$ and acetate. Thereafter, acetate was oxidized to $\mathrm{CO}_{2}$. In addition, strain $10 \mathrm{C}^{\mathrm{T}}$ was catalasepositive and oxidase-negative, reduced nitrate to nitrite but did not reduce the sulfur compounds tested (elemental sulfur, sulfate, thiosulfate and sulfite).

The dendrogram including all Exiguobacterium species (Fig. 1) revealed unambiguously two distinct clusters. Cluster I comprised E. aurantiacum, E. mexicanum, E. aestuarii, E. marinum and strain $10 \mathrm{C}^{\mathrm{T}}$ and cluster II comprised E. acetylicum, E. oxidotolerans, E. sibiricum, E. artemiae, E. antarcticum and E. undae. In contrast to members of cluster II, it was noteworthy that members of cluster I reduced nitrate to nitrite and were oxidase-negative, except for E. mexicanum, which was oxidase-positive
(Table 1). Differential physiological characteristics for members of cluster I are given in Table 1.

As with other members of the genus Exiguobacterium, strain $10 \mathrm{C}^{\mathrm{T}}$ contained MK7 (82\%), MK8 (14\%) and MK6 (4\%) as major menaquinones, and polar lipids found were diphosphatidylglycerol, phosphatidylglycerol, phosphatidylethanolamine and two unidentified phospholipids. The qualitative profile of branched-chain fatty acids for strain $10 \mathrm{C}^{\mathrm{T}}$ was close to that for E. marinum, E. aestuarii and E. aurantiacum, iso- $\mathrm{C}_{13: 0}$, anteiso- $\mathrm{C}_{13: 0}$, iso- $\mathrm{C}_{15: 0}$ and iso- $\mathrm{C}_{17: 0}$ fatty acids being the predominant components (Table 2). However, the amount of these branched-chain fatty acids in strain $10 \mathrm{C}^{\mathrm{T}}$ differed markedly from that in the type strains of E. marinum and E. aestuarii, its closest phylogenetic relatives. Notably, $\mathrm{C}_{16: 1} \omega 7 c$ and $\mathrm{C}_{16: 1} \omega 11 c$ were detected in strain $10 \mathrm{C}^{\mathrm{T}}$ but not in E. aestuarii or E. marinum. Moreover, iso- $\mathrm{C}_{17: 1} \omega 10 c$ was found in significantly smaller proportions in E. aestuarii and E. marinum. Finally, based on their fatty acid profiles, E. marinum and E. aestuarii are more closely related to each other than to strain $10 C^{\mathrm{T}}$. Differences in the fatty acid profiles of strain $10 \mathrm{C}^{\mathrm{T}}$ and E. mexicanum were also observed (Table 2), but these may result from the culture conditions used to obtain biomass in each case.

In addition, despite phylogenetic similarities between strain $10 \mathrm{C}^{\mathrm{T}}$, E. aestuarii and E. marinum, levels of DNA-DNA relatedness $\left(25 \%\right.$ between strain $10 \mathrm{C}^{\mathrm{T}}$ and E. aestuarii $\mathrm{TF}-$ $16^{\mathrm{T}} ; 21 \%$ between strain $10 \mathrm{C}^{\mathrm{T}}$ and E. marinum $\mathrm{TF}-80^{\mathrm{T}}$ ) revealed that strain $10 \mathrm{C}^{\mathrm{T}}$ should be assigned novel species status within the genus Exiguobacterium (Wayne et al., 1987).

Based on its phylogenetic, genotypic and phenotypic characteristics, strain $10 \mathrm{C}^{\mathrm{T}}$ is considered to represent a novel species of the genus Exiguobacterium, for which the name Exiguobacterium profundum sp. nov. is proposed.

\section{Description of Exiguobacterium profundum sp. nov.}

Exiguobacterium profundum (pro.fun'dum. L. neut. adj. profundum deep, living within the depth of the oceans). 
Table 1. Differential characteristics between strain $10 \mathrm{C}^{\top}$ and the type strains of members of Exiguobacterium cluster I

Strains: 1, strain $10 \mathrm{C}^{\mathrm{T}}$; 2, E. aestuarii DSM $16306^{\mathrm{T}}$ (data from Kim et al., 2005; Lopez-Cortes et al., 2006); 3, E. marinum DSM $16307^{\mathrm{T}}$ (Kim et al., 2005; Lopez-Cortes et al., 2006); 4, E. mexicanum DSM $16483^{\mathrm{T}}$ (Lopez-Cortes et al., 2006); 5, E. aurantiacum DSM $6208^{\mathrm{T}}$ (Collins et al., 1983; Lopez-Cortes et al., 2006). All strains were catalase-positive, and positive for acid production from aesculin, D-fructose, gentiobiose, D-glucose, maltose, D-mannitol, $N$-acetylglucosamine, salicin, sucrose and trehalose. All strains were negative for acid production from adonitol, D-arabinose, D-arabitol, dulcitol, D-fucose, D-lyxose, D-melezitose, D-sorbitol, erythritol, inulin, L-rhamnose, L-sorbose and xylitol. W, Weak; ND, no data available.

\begin{tabular}{|c|c|c|c|c|c|}
\hline Characteristic & 1 & 2 & 3 & 4 & 5 \\
\hline $\begin{array}{l}\text { Temperature range } \\
\left({ }^{\circ} \mathrm{C}\right)\end{array}$ & $12-49$ & $10-47$ & $10-43$ & $20-41$ & $7-43$ \\
\hline $\begin{array}{l}\text { Temperature } \\
\text { optimum }\left({ }^{\circ} \mathrm{C}\right)\end{array}$ & 45 & $30-37$ & $30-37$ & ND & 37 \\
\hline $\mathrm{NaCl}$ range $(\%)$ & $0-11$ & $0-19$ & $0-17$ & ND & ND \\
\hline Oxidase & - & - & - & + & - \\
\hline $\begin{array}{l}\text { Nitrate to nitrite } \\
\text { Acid production fro }\end{array}$ & + & + & + & ND & + \\
\hline Amygdalin & $\mathrm{W}$ & + & + & + & + \\
\hline Arbutin & + & + & + & $\mathrm{W}$ & + \\
\hline Cellobiose & + & + & + & + & - \\
\hline D-Galactose & + & + & - & - & - \\
\hline Glycerol & - & + & + & $\mathrm{W}$ & + \\
\hline Lactose & - & $\mathrm{W}$ & + & - & - \\
\hline D-Mannose & + & - & + & - & - \\
\hline Melibiose & - & + & - & - & - \\
\hline D-Raffinose & - & - & $\mathrm{W}$ & - & - \\
\hline D-Ribose & + & + & + & + & - \\
\hline D-Xylose & - & - & - & + & - \\
\hline $\begin{array}{l}\text { DNA G }+\mathrm{C} \\
\text { content }(\mathrm{mol} \%)\end{array}$ & 50.4 & 48.5 & 48.0 & $\mathrm{ND}$ & $53.2-55.8^{*}$ \\
\hline
\end{tabular}

*Determined by two different methods by Collins et al. (1983).

Gram-positive, non-sporulating rods, $0.5-1.0 \times 2-10 \mu \mathrm{m}$, occurring singly, in pairs or in short chains, and motile by means of peritrichous flagella. Colonies are circular (1-2 mm) and creamy or orange under anaerobic or aerobic conditions. Chemo-organotrophic and facultatively anaerobic. Catalase-positive and oxidase-negative. It is moderately thermophilic (growth between 12 and $49^{\circ} \mathrm{C}$, no growth at $50{ }^{\circ} \mathrm{C}$, optimum at $45^{\circ} \mathrm{C}$ ) and halotolerant (growth in the presence of $11 \% \mathrm{NaCl}$, optimum $0-2 \%$ $\mathrm{NaCl}$ ). $\mathrm{pH}$ range for growth is 5.5-9.5 (optimum $\mathrm{pH}$ 7.0). Yeast extract is required to use sugars. (+)-L-Lactate is the main organic acid detected (about 2 moles lactate are produced per mole glucose fermented) from carbohydrate fermentation, with traces of formate, acetate and ethanol being produced. Substrates used for growth under anaerobic
Table 2. Fatty acid compositions (\%) of strain $10 \mathrm{C}^{\top}$ and the type strains of members of Exiguobacterium cluster I

Strains: 1, strain $10 \mathrm{C}^{\mathrm{T}}$; 2, E. aestuarii DSM $16306^{\mathrm{T}}$ (data from Kim et al., 2005); 3, E. marinum DSM $16307^{\mathrm{T}}$ (Kim et al., 2005); 4, E. mexicanum DSM $16483^{\mathrm{T}}$ (Lopez-Cortes et al., 2006); 5, E. aurantiacum DSM $6208^{\mathrm{T}}$ (Kim et al., 2005). Major components $(>10 \%)$ are indicated in bold. - , Not detected.

\begin{tabular}{|c|c|c|c|c|c|}
\hline Fatty acid & 1 & 2 & 3 & 4 & 5 \\
\hline \multicolumn{6}{|l|}{ Straight chain } \\
\hline $\mathrm{C}_{12: 0}$ & - & - & - & 8.3 & - \\
\hline $\mathrm{C}_{14: 0}$ & 0.4 & - & - & 6.1 & - \\
\hline $\mathrm{C}_{16: 0}$ & 3.1 & 5.3 & 4.3 & 32.8 & 4.4 \\
\hline $\mathrm{C}_{18: 0}$ & - & 1.7 & 0.8 & 7.0 & 0.7 \\
\hline \multicolumn{6}{|l|}{ Branched } \\
\hline iso- $\mathrm{C}_{11: 0}$ & - & - & - & 1.5 & - \\
\hline iso- $\mathrm{C}_{12: 0}$ & 1.9 & 1.7 & 2.6 & 2.1 & 3.4 \\
\hline iso- $\mathrm{C}_{13: 0}$ & 13.3 & 11.5 & 11.5 & 11.2 & 11.5 \\
\hline anteiso- $\mathrm{C}_{13: 0}$ & 16.1 & 15.6 & 18.1 & 8.9 & 19.5 \\
\hline iso- $\mathrm{C}_{14: 0}$ & 1.4 & 1.3 & 0.8 & - & 0.7 \\
\hline iso- $\mathrm{C}_{15: 0}$ & 17.8 & 13.1 & 10.4 & 1.7 & 10.4 \\
\hline anteiso- $\mathrm{C}_{15: 0}$ & 3.5 & 3.2 & 2.6 & - & 2.3 \\
\hline iso- $\mathrm{C}_{16: 0}$ & 4.4 & 7.1 & 5.0 & - & 4.0 \\
\hline iso- $\mathrm{C}_{17: 0}$ & 15.4 & 27.2 & 34.4 & - & 28.7 \\
\hline anteiso- $\mathrm{C}_{17: 0}$ & 6.3 & 8.2 & 7.1 & - & 8.3 \\
\hline iso- $\mathrm{C}_{18: 0}$ & 0.6 & 2.2 & 1.2 & - & 0.6 \\
\hline \multicolumn{6}{|l|}{ Unsaturated } \\
\hline $\mathrm{C}_{16: 1} \omega 7 c$ & 3.7 & - & - & 6.5 & - \\
\hline $\mathrm{C}_{16: 1} \omega 11 c$ & 2.9 & - & - & 10.3 & 1.3 \\
\hline iso- $\mathrm{C}_{17: 1} \omega 10 c$ & 7.3 & 1.1 & 0.9 & - & 1.8 \\
\hline
\end{tabular}

conditions are aesculin, amygdalin (weakly), arbutin, cellobiose, D-fructose, D-galactose, $N$-acetyl-D-glucosamine, D-glucose, gentiobiose, maltose, D-mannitol, D-mannose, D-ribose, salicin, starch, sucrose and trehalose. Substrates used for growth under aerobic conditions are acetate, aesculin, amygdalin, cellobiose, D-fructose, D-galactose, Dglucose, glycerol, L-lactate (weakly), lactose (weakly), maltose, D-mannitol, D-mannose, melibiose, pyruvate, Draffinose, D-ribose, salicin, starch, sucrose and trehalose. No anaerobic or aerobic growth in the presence of the following substrates: D-arabinose, benzoate, butyrate, dulcitol, formate, fumarate, inulin, D-melezitose, propionate, L-rhamnose, L-sorbose and D-xylose. Elemental sulfur, sulfate, thiosulfate, sulfite and nitrite are not used as electron acceptors. Nitrate is reduced to nitrite. The peptidoglycan type is L-Lys-Gly. The major menaquinones are MK7 (82\%), MK6 (4\%) and MK8 (14\%). The branched-chain saturated fatty acids iso- $\mathrm{C}_{13: 0}$, anteiso- $\mathrm{C}_{13: 0}$, iso- $\mathrm{C}_{15: 0}$ and iso- $\mathrm{C}_{17: 0}$ represent the major fatty acids of the cellular membrane. The major polar lipids are diphosphatidylglycerol, phosphatidylglycerol and phosphatidylethanolamine. The DNA G + C content is $50.4 \mathrm{~mol} \%$.

The type strain, $10 C^{\mathrm{T}}\left(=\right.$ CCUG $50949^{\mathrm{T}}=$ DSM $\left.17289^{\mathrm{T}}\right)$, was isolated from deep-sea hydrothermal vent samples 
collected on the $13^{\circ} \mathrm{N}$ East Pacific Rise at a depth of approximately $2600 \mathrm{~m}$.

\section{Acknowledgements}

The Amistad cruise was organized by the Centre National de la Recherche Scientifique. We thank C. Jeanthon and D. Prieur for the invitation to J.-L.C. and B. O. to participate in the cruise. We thank the captain and crew of the R/V l'Atalante and especially the pilots of the DSV Nautile for their essential roles in sample collection.

\section{References}

Alain, K., Quérellou, J., Lesongeur, F., Pignet, P., Crassous, P., Raguénès, G., Cueff, V. \& Cambon-Bonavita, M. A. (2002a). Caminibacter hydrogenophilus gen. nov., sp. nov., a novel thermophilic hydrogen-oxidizing bacterium isolated from an East-Pacific Rise hydrothermal vent. Int J Syst Evol Microbiol 52, 1317-1323.

Alain, K., Pignet, P., Zbinden, M., Quillevere, M., Duchiron, F., Donval, J. P., Lesongeur, F., Raguenes, G., Crassous, P. \& other authors (2002b). Caminicella sporogenes gen. nov., sp. nov., a novel thermophilic spore-forming bacterium isolated from an East-Pacific Rise hydrothermal vent. Int J Syst Evol Microbiol 52, 1621-1628.

Altschul, S. F., Madden, T. L., Schäffer, A. A., Zhang, J., Zhang, Z., Miller, W. \& Lipman, D. J. (1997). Gapped BLAST and PSI-BLAST: a new generation of protein database search programs. Nucleic Acids Res 25, 3389-3402.

Ash, C., Farrow, J. A. E., Wallbanks, S. \& Collins, M. D. (1991) Phylogenetic heterogeneity of the genus Bacillus revealed by comparative analysis of small-subunit ribosomal RNA sequences. Lett Appl Microbiol 13, 202-206.

Balch, W. E., Fox, G. E., Magrum, R. J. \& Wolfe, R. S. (1979). Methanogens: reevaluation of a unique biological group. Microbiol Rev 43, 260-296.

Baross, J. A. \& Deming, J. W. (1995). Growth at high temperature: isolation and taxonomy, physiology, ecology. In The Microbiology of Deep-Sea Hydrothermal Vents, pp. 169-217. Edited by D. M. Karl. Boca Raton, FL: CRC Press.

Ben Dhia-Thabet, O., Fardeau, M.-L., Joulian, C., Thomas, P., Hamdi, M., Garcia, J.-L. \& Ollivier, B. (2004). Clostridium tunisiense sp. nov., a new proteolytic, sulfur-reducing bacterium isolated from an olive mill wastewater contaminated by phosphogypse. Anaerobe 10, 185-190.

Benson, D. A., Boguski, M. S., Lipman, D. J., Ostell, J., Ouellette, B. F. F., Rapp, B. A. \& Wheeler, D. L. (1999). GenBank. Nucleic Acids Res 27, 12-17.

Bowers, T. S., Campbell, A. C., Mesures, C. I., Spivack, A. J., Khadem, M. \& Edmond, J. M. (1988). Chemical controls on the composition of vent fluids at $13^{\circ} \mathrm{N}, 11^{\circ} \mathrm{N}$ and $21^{\circ} \mathrm{N}$, East Pacific Rise. J Geophys Res 93, 4522-4536.

Brisbarre, N., Fardeau, M.-L., Cueff, V., Cayol, J. L., Barbier, G., Cilia, V., Ravot, G., Thomas, P., Garcia, J. L. \& Ollivier, B. (2003). Clostridium caminithermale sp. nov., a slightly halophilic and moderately thermophilic bacterium isolated from an Atlantic deep-sea hydrothermal chimney. Int J Syst Evol Microbiol 53, 1043-1049.

Campbell, B. J., Jeanthon, C., Kotska, J. E., Luther, G. W., III \& Cary, S. C. (2001). Growth and phylogenetic properties of novel bacteria belonging to the epsilon subdivision of the Proteobacteria enriched from Alvinella pompejana and deep-sea hydrothermal vents. Appl Environ Microbiol 67, 4566-4572.
Cayol, J.-L., Ollivier, B., Soh, A. L. A., Fardeau, M. L., Ageron, E., Grimont, P. A. D., Prensier, G., Guezennec, J., Magot, M. \& Garcia, J. L. (1994). Haloincola saccharolytica subsp. senegalensis subsp. nov., isolated from the sediments of a hypersaline lake, and emended description of Haloincola saccharolytica. Int J Syst Bacteriol 44, 805-811.

Collins, M. D., Lund, B. M., Farrow, J. A. E. \& Schleifer, K. H. (1983). Chemotaxonomic study of an alkalophilic bacterium, Exiguobacterium aurantiacum gen. nov., sp. nov. J Gen Microbiol 129, 2037-2042.

Edmond, J. M. \& Von Damm, K. L. (1985). Chemistry of ridge crest hot springs. Biol Soc Wash Bull 6, 43-47.

Fardeau, M.-L., Cayol, J.-L., Magot, M. \& Ollivier, B. (1993). $\mathrm{H}_{2}$ oxidation in the presence of thiosulfate, by a Thermoanaerobacter strain isolated from an oil-producing well. FEMS Microbiol Lett 113, 327-332.

Farrow, J. A. E., Wallbanks, S. \& Collins, M. D. (1994). Phylogenetic interrelationships of round spore-forming bacilli containing cell walls based on lysine and the non-spore-forming genera Caryophanon, Exiguobacterium, Kurthia, and Planococcus. Int J Syst Bacteriol 44, 74-82.

Felsenstein, J. (1985). Confidence limits on phylogenies: an approach using the bootstrap. Evolution 39, 783-791.

Frühling, A., Schumann, P., Hippe, H., Straübler, B. \& Stackebrandt, E. (2002). Exiguobacterium undae sp. nov. and Exiguobacterium antarcticum sp. nov. Int J Syst Evol Microbiol 52, 1171-1176.

Götz, D., Banta, A., Beveridge, T. J., Rushdi, A. I., Simoneit, B. R. T. \& Reysenbach, A. L. (2002). Persephonella marina gen. nov., sp. nov. and Persephonella guaymasensis sp. nov., two novel thermophilic hydrogen-oxidizing microaerophiles from deep-sea hydrothermal vents. Int J Syst Evol Microbiol 52, 1349-1359.

Groth, I., Schumann, P., Weiss, N., Martin, K. \& Rainey, F. A. (1996). Agrococcus jenensis gen. nov., sp. nov., a new genus of actinomycetes with diaminobutyric acid in the cell wall. Int J Syst Bacteriol 46, 234-239.

Hall, T. A. (1999). BIOEDIT: a user-friendly biological sequence alignment editor and analysis program for Windows 95/98/NT. Nucleic Acids Symp Ser 41, 95-98.

Hungate, R. E. (1969). A roll-tube method for the cultivation of strict anaerobes. Methods Microbiol 3B, 117-132.

Jeanthon, C. (2000). Molecular ecology of hydrothermal vent microbial communities. Antonie van Leeuwenhoek 77, 117-133.

Jeanthon, C., L'Haridon, S., Reysenbach, A. L., Vernet, M., Messner, P., Sleytr, U. W. \& Prieur, D. (1998). Methanococcus infernus sp. nov., a novel hyperthermophilic lithotrophic methanogen isolated from a deep-sea hydrothermal vent. Int J Syst Bacteriol 48, 913-919.

Jones, D. \& Keddie, R. M. (1986). Genus Brevibacterium Breed 1953. In Bergey's Manual of Systematic Bacteriology, vol. 2, pp. 1301-1313. Edited by P. H. A. Sneath, N. S. Mair, M. E. Sharpe \& J. G. Holt. Baltimore: Williams \& Wilkins.

Jukes, T. H. \& Cantor, C. R. (1969). Evolution of protein molecules. In Mammalian Protein Metabolism, pp. 211-232. Edited by H. N. Munro. New York: Academic Press.

Juniper, S. K. \& Sarrizan, J. (1995). Interaction of vent biota and hydrothermal deposits: present evidence and future experimentation. In Seafloor Hydrothermal Systems: Physical, Chemical, Biological and Geological Interactions, pp. 178-193. Edited by S. E. Humpris, R. A. Zierenberg, L. S. Mullineaux \& R. E. Thomson. Washington, DC: American Geophysical Union.

Karl, D. M. (1995). Ecology of free-hydrothermal vent microbial communities. In The Microbiology of Deep-Sea Hydrothermal Vents, pp. 35-124. Edited by D. M. Karl. Boca Raton, FL: CRC Press Inc. 
Kim, I. J., Lee, M. H., Jung, S. Y., Song, J. J., Oh, T. K. \& Yoon, J. H. (2005). Exiguobacterium aestuarii sp. nov. and Exiguobacterium marinum sp. nov., isolated from tidal flat of the Yellow Sea in Korea. Int J Syst Evol Microbiol 55, 885-889.

L'Haridon, S., Cilia, V., Messner, P., Raguénès, G., Gambacorta, A., Sleytr, U. W., Prieur, D. \& Jeanthon, C. (1998). Desulfurobacterium thermolithotrophicum gen. nov., sp. nov., a novel autotrophic, sulfurreducing bacterium isolated from a deep-sea hydrothermal vent. Int J Syst Bacteriol 48, 701-711.

Lopez-Cortes, A., Schumann, P., Pukall, R. \& Stackebrandt, E. (2006). Exiguobacterium mexicanum sp. nov. and Exiguobacterium artemiae sp. nov., isolated from the brine shrimp Artemia franciscana. Syst Appl Microbiol 29, 183-190.

Luther, G. W., Glazer, B. T., Hohmann, L., Popp, J. I., Taillefert, M., Rozan, T. F., Brendel, P. J., Theberg, S. M. \& Nuzzio, D. B. (2001a). Sulfur speciation monitored in situ with solid state gold amalgam voltammetric microelectrodes: polysulfides as a special case in sediments, microbial mats and hydrothermal vent waters. J Environ Manage 62, 61-66.

Luther, G. W., Rozan, T. F., Taillefert, M., Nuzzio, D. B., Di Meo, C., Shank, T. M., Lutz, R. A. \& Cary, S. C. (2001b). Chemical speciation drives hydrothermal vent ecology. Nature 410, 813-816.

MacKenzie, S. L. (1987). Gas chromatographic analysis of amino acids as the $N$-heptafluorobutyryl isobutyl esters. J Assoc Off Anal Chem 70, 151-160.

Maidak, B. L., Cole, J. R., Lilburn, T. G., Parker, C. T., Jr, Saxman, P. R., Farris, R. J., Garrity, G. M., Olsen, G. J., Schmidt, T. M. \& Tiedje, J. M. (2001). The RDP-II (Ribosomal Database Project). Nucleic Acids Res 29, 173-174.

Michard, G. F., Albarède, A., Michard, J. F., Minster, J., Charlou, L. \& Tan, N. (1984). Chemistry of solutions from the $13^{\circ} \mathrm{N}$ East Pacific Rise hydrothermal site. Earth Planet Sci Lett 67, 297-307.

Reysenbach, A. L., Banta, A., Boone, D. R., Cary, S. C. \& Luther, G. W. (2000a). Microbial essentials at hydrothermal vents. Nature 404, 835-836.

Reysenbach, A. L., Longnecker, K. \& Kirshtein, J. (2000b). Novel bacterial and archaeal lineages from an in situ growth chamber deployed at the Mid-Atlantic Ridge hydrothermal vent. Appl Environ Microbiol 66, 3798-3806.
Rodrigues, D. F., Goris, J., Vishnivetskaya, T., Gilichinsky, D., Thomashow, M. F. \& Tiedje, J. M. (2006). Characterization of Exiguobacterium isolates from the Siberian permafrost. Description of Exiguobacterium sibiricum sp. nov. Extremophiles 10, 285-294.

Rozan, T. F., Theberge, S. M. \& Luther, G. (2000). Quantifying elemental sulfur $\left(\mathrm{S}^{0}\right)$, bisulfide $\left(\mathrm{HS}^{-}\right)$and polysulfides $\left(\mathrm{S}_{\mathrm{x}}{ }^{2-}\right)$ using a voltammetric method. Anal Chim Acta 415, 175-184.

Saitou, N. \& Nei, M. (1987). The neighbor-joining method: a new method for reconstructing phylogenetic trees. Mol Biol Evol 4, 405-425.

Schleifer, K. H. (1985). Analysis of the chemical composition and primary structure of murein. Methods Microbiol 18, 123-156.

Schleifer, K. H. \& Kandler, O. (1972). Peptidoglycan types of bacterial cell walls and their taxonomic implications. Bacteriol Rev 36, 407-477.

Von Damm, K. L., Edmond, J. M., Mesures, C. I. \& Grant, B. (1985a). Chemistry of submarine hydrothermal solutions at Guaymas Basin, Gulf of California. Geochim Cosmochim Acta 49, 213-229.

Von Damm, K. L., Edmond, J. M., Grant, B., Mesures, C. I., Walden, B. \& Weiss, R. F. (1985b). Chemistry of submarine hydrothermal solutions at $21^{\circ} \mathrm{N}$, East Pacific Rise. Geochim Cosmochim Acta 49, 2197-2220.

Wayne, L. G., Brenner, D. J., Colwell, R. R., Grimont, P. A. D., Kandler, O., Krichevsky, M. I., Moore, L. H., Moore, W. E. C., Murray, R. G. E. \& other authors (1987). International Committee on Systematic Bacteriology. Report of the ad hoc committee on reconciliation of approaches to bacterial systematics. Int J Syst Bacteriol 37, 463-464.

Wery, N., Moricet, J. M., Cueff, V., Jean, J., Pignet, P., Lesongeur, F., Cambon-Bonavita, M.-A. \& Barbier, G. (2001). Caloranaerobacter azorensis gen. nov., an anaerobic thermophilic bacterium isolated from a deep-sea hydrothermal vent. Int J Syst Evol Microbiol 51, 1789-1796.

Winker, S. \& Woese, C. R. (1991). A definition of the domain Archaea, Bacteria and Eucarya in terms of small subunit ribosomal RNA characteristics. Syst Appl Microbiol 13, 161-165.

Yumoto, I., Hishinuma-Narisawa, M., Hirota, K., Shingyo, T., Takebe, F., Nodasaka, Y., Matsuyama, H. \& Hara, I. (2004). Exiguobacterium oxidotolerans sp. nov., a novel alkaliphile exhibiting high catalase activity. Int J Syst Evol Microbiol 54, 2013-2017. 